\title{
Behavioral activities of white-lipped peccary (Tayassu pecari, Link, 1795) in a semi-intensive farming system in Brazil
}

J.M. Malheiros

https://orcid.org/000

[Atividades comportamentais de queixadas (Tayassu pecari, Link, 1795) em sistema

semi-intensivo de criação no Brasil]



\begin{abstract}
This study aimed to describe the main behaviors of white-lipped peccaries (Tayassu pecari) expressed in a semiintensive production system in Brazil. The behavioral activities of two groups of peccaries allocated in two paddocks were assessed, totaling 17 adult animals and eventual pups in different developmental stages. The animals were visually observed using the ad libitum sampling and scan sample methods during the adaptation and experimental phases, respectively. The animals were evaluated in the morning, afternoon, and at night. The behavioral activities observed by ad libitum sampling comprised feeding, pool contact, moving, staying inside the handling area, resting, mud bathing, mutual rubbing, rubbing, aggression, sexual behavior, copulation, foraging, breastfeeding, sleeping, territorial marking, interactions, birthing, gnawing, and other behaviors. All behaviors observed by the ad libitum sampling method were confirmed in the experimental period by scan sample, except for territorial marking and birthing. The effects of time of day were statistically significant ( $\mathrm{p}$ $<0.05$ ) for eating, pool contact, movement, staying inside the handling area, resting, mud bathing and sleeping. These results contribute to the understanding of instinctive animal habits and to the development of nutritional, environmental and health management protocols that meet the requirements of peccaries.
\end{abstract}

Keywords: animal welfare, animal production, conservation, ethology, wildlife

\section{RESUMO}

Objetivou-se descrever os principais comportamentos que os queixadas (Tayassu pecari) expressam em sistema de produção semi-intensivo no Brasil, bem como suas diferenças de frequências comportamentais em função do período do dia. Foram avaliadas as atividades comportamentais de dois grupos de queixadas alocados em dois piquetes, totalizando 17 animais adultos e eventuais filhotes em diferentes estágios comportamentais. Na fase adaptativa e experimental os animais foram observados visualmente pelos métodos ad libitum e scan sample, respectivamente. Os animais foram avaliados nos períodos da manhã, tarde e noite. As atividades comportamentais observadas pelo método ad libitum foram alimentação, contato com a piscina, movimentação, interior do brete de manejo, descanso, lameando, esfregação mútua, esfregar-se, agressão, comportamento sexual, cópula, fuçando, amamentação, dormindo, marcando território, interações, manilha, parição, roendo e outros comportamentos. Todos os comportamentos observados pelo método ad libitum foram confirmados no período experimental scan sample, exceto para as variáveis marcando território e parição. $O$ efeito do período do dia foi estatisticamente significativo $(P<0,05)$ sobre as frequências dos comportamentos alimentação, contato com a piscina, movimentação, interior do brete de manejo, descanso, lameando e dormindo. Os resultados contribuem para a compreensão dos hábitos instintivos dos animais e, com isso, colaborar com a elaboração de

Recebido em 7 de abril de 2020

Aceito em 17 de junho de 2020

E-mail: matheusvargasoliveira@hotmail.com 
protocolos de manejo nutricional, ambiental e sanitário, buscando-se suprir as necessidades dos queixadas. Futuras pesquisas envolvendo queixadas em cativeiro fomentarão os estudos voltados aos aspectos biológicos, conservacionistas e produtivos.

Palavras-chave: bem-estar animal, produção animal, conservação, etologia, animais silvestres

\section{INTRODUCTION}

The zootechnical exploitation of unconventional species to meet growing animal protein demands is interesting and promising (Hoffman, 2016). In addition, there is increasing interest of farmers in these species because of the high added value of their meat, which may represent a mechanism of biodiversity conservation.

Unlike predatory hunting in Brazil, the production of peccary (Tayassu pecari, Link, 1975) offers new perspectives for the meat, skin and leather industries. Peccary meat is greatly appreciated by national and international consumers because of its quality and sensory characteristics; however, studies on this species are still scarce (Kumar, 2018). The skin and leather used by foreign industries serve as a specific niche market for the production of luxury goods (Sowls, 1984; Fang et al., 2008). In addition, peccary rearing may be a solution for the use of unproductive areas on rural properties, as this species can adapt to different environments (Fang et al., 2008).

Knowledge on peccary biology is derived mainly from the studies of Kiltie (1982) and Kiltie and Terborgh (1983), who described some aspects of the behavioral ecology of these animals through signals left by group displacement. In nature, these animals are characterized by social groups of up to 200 individuals (Kiltie and Terborgh, 1983), composed of different age and sex groups (Ellison and Harwell, 1969), which form relatively stable social units (Schweinsburg, 1971). Descriptions of their natural behavior indicate that peccaries can be rationally explored in semi-intensive farming systems characterized by natural/artificial pasture feeding plus supplementation. The success of this activity requires knowledge of the biology, nutrition, health, behavior and welfare of captive individuals to overcome management problems and for the formation of groups and construction of adequate facilities that will ensure animal welfare and high production. In this context, the aim of this study was to describe the main behaviors of peccaries in a semi-intensive production system in Brazil and to evaluate differences in the frequency of these behaviors between different times of day.

\section{MATERIAL AND METHODS}

The study was approved by the Ethics Committee on the Use of Animal at the Federal University of São João del-Rei, São João del-Rei, Minas Gerais, Brazil (Protocols n. 008/2016).

The experiment was carried out on a privately owned farm located in the municipality of Conceição da Barra de Minas, Minas Gerais,

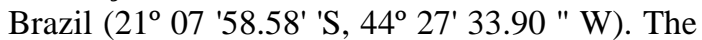
property was registered with the State Forest Institute (IEF), through Normative Instruction No. 7 of April 30, 2015, which provides authorization for wildlife management, under No. 3115.8983/2014-MG.

The behavioral activities of two groups of peccaries allocated in two paddocks were evaluated. Paddock one consisted of eight breeding animals and paddock two consisted of seven breeding animals, each containing one breeding male, totaling 17 adult animals and eventual pups in different developmental stages.

The paddocks were separated by fences $(100 \mathrm{~m}$ long $\mathrm{x} 12 \mathrm{~m}$ wide) and contained a drinking fountain $(0.80 \times 0.40 \times 0.20 \mathrm{~m})$, feeder $(3 \times 0.40 \times$ $0.20 \mathrm{~m})$, management area $(5 \times 3 \times 3 \mathrm{~m})$, masonry pool $(3 \times 2 \times 0.40 \mathrm{~m})$, and a shelter consisting of four reinforced concrete shackles $(0.5 \mathrm{~m}$ internal diameter $\times 1.5 \mathrm{~m}$ high $\times 0.05 \mathrm{~m}$ thick). Lighting was provided by 22 fluorescent lamps. The pasture area consisted of Urochloa decumbens Stapf. Prain cv. Basilisk and there was a vegetation area formed by Eucalyptus, according to the 2016 schematic representation of the property (Figure 1).

The animals were fed twice a day at 6 am and 3 pm, with a diet consisting of $30 \%$ of feed based on $70 \%$ of disintegrated corn with straw and cob, $19 \%$ of wheat bran, $10 \%$ of soybean meal and $1 \%$ of mineral salt, supplied by the feeder in the 
management area feeder. The remaining 70\% consisted of vegetables, legumes, fruits, sugar cane (Saccharum officinarum L.), elephant grass (Pennisetum purpureum cv. Schum), banana stem (Musa sapientum L.),manioc (Manihot esculenta L Crantz), corn kernel (Zeamays L.) and whey supplementation, supplied by the management area feeder or directly on the paddock floor. Waste and food scraps were removed every day. The animals were dewormed, and no vaccines were administered during the experimental period.

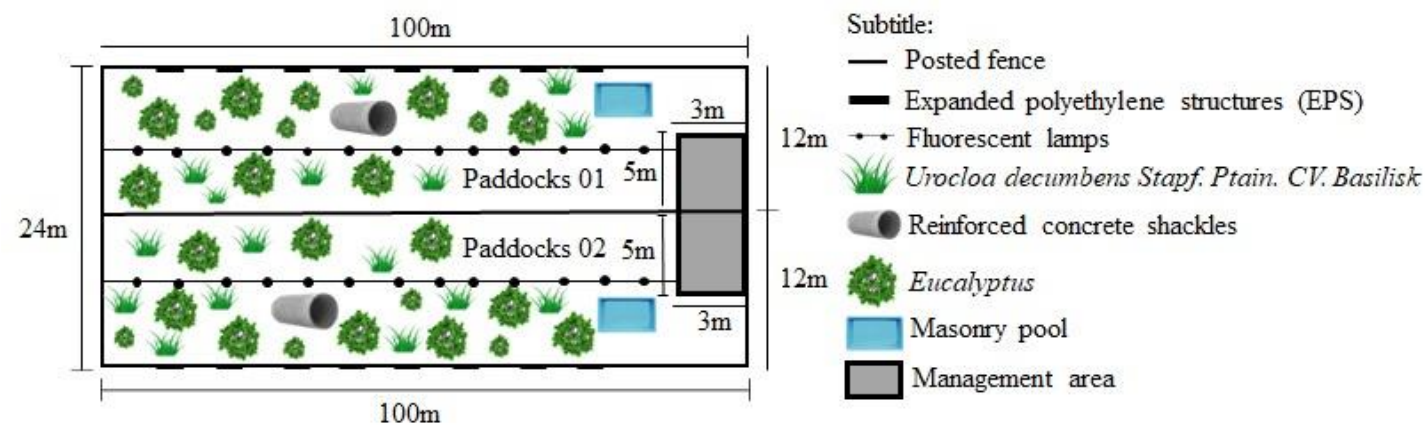

Figure 1. Schematic representation of the peccary paddocks.

Eight expanded polyethylene structures were assembled with small windows distributed every $12.5 \mathrm{~m}$ in total length in each paddock, in order to minimize observer interference with animal behavior. These structures allowed for data collection throughout the paddock. The adaptation phase comprised the period from October to December 2015. The animals were visually observed by the ad libitum sampling method, which consists of recording all behavioral events without any methodological limitation (Martin and Bateson, 2007). The peccaries were accustomed to the presence of the observers and the modifications made in the experimental environment. Observations during the adaptation period were performed within four days. According to the National Institute of Meteorology (Estação..., 2019), the temperature range, relative humidity and rainfall during this period was of 21.8 to $23.3^{\circ} \mathrm{C}$; 63.8 to $71.40 \%$ and $0.2 \mathrm{~mm}$, respectively.

Starting the experimental phase of the study, the animals were visually observed by the scan sample sampling method, in which the behavior of the animals was recorded at regular time intervals (Altmann, 1974), regardless of paddock location. These observations were conducted between December 2015 and May 2016 at 15-day intervals, totaling 10 observations. According to the National Institute of Meteorology (Estação..., 2019), the temperature range, relative humidity and rainfall in this period was of 21 to $22.5^{\circ} \mathrm{C}$; 71.1 to $78.0 \%$ and $0.1 \mathrm{~mm}$, respectively.

Discontinuous data collection was used, with two hours of observation (recording of behaviors every $5 \mathrm{~min}$ ), followed by two hours of nonobservation. The animals were assessed in the morning (5 am to $11 \mathrm{am}$ ), afternoon (1 pm to 7 $\mathrm{pm}$ ) and night ( $9 \mathrm{pm}$ to $3 \mathrm{am}$ ). Behavioral patterns were recorded by two previously trained observers. The frequency of the behaviors and the effects of time (morning, afternoon and evening) on the behavioral variables were evaluated using the PROC FREQ procedure of the Statistical Analysis System ${ }^{\circledR}$ software (SAS Institute, Cary, NC, USA, 2011). The chi-square test was applied and a level of statistical significance of $5 \%$ was adopted.

\section{RESULTS}

An ethogram was elaborated based on 19 peccary behaviors during the adaptation period obtained by the ad libitum sampling method (Table 1). Maintenance behaviors (feeding, moving, staying inside the handling area, resting, and sleeping), reproductive behaviors (pool contact, mud bathing, foraging, shackle, and gnawing), environmental enrichment behaviors (sexual behavior, copulation, breastfeeding, territorial marking, and birthing), and conspecific and agonistic behaviors (mutual rubbing, rubbing, aggression, and interactions) were observed. 
Table 1. Ethogram of peccaries elaborated by ad libitum sampling method

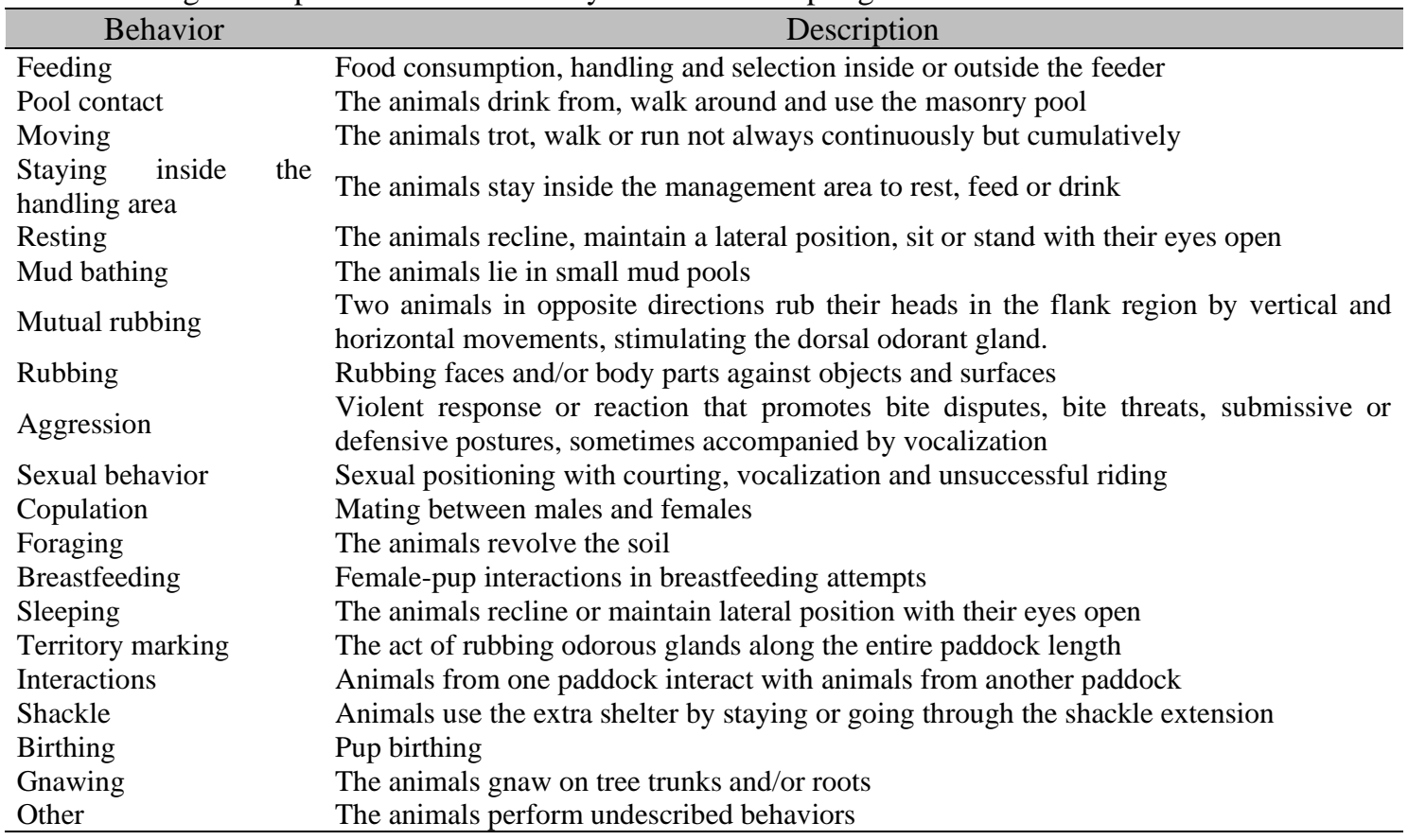

All behaviors were confirmed in the experimental period by scan sample, except for territorial marking and birthing. The effects of time were not statistically significant $(\mathrm{P}>0.05)$ for mutual rubbing, rubbing, aggression, sexual behavior, copulation, foraging, breastfeeding, interactions, shackle, gnawing, and other behaviors (Table 2), but were significant $(\mathrm{P}<0.05)$ for eating, pool contact, movement, staying inside the handling area, rest, mud bathing and sleeping. The time of day exerted a significant effect.

Table 2. Frequencies of behavioral activities of peccaries as a function of time of day

\begin{tabular}{|c|c|c|c|c|c|}
\hline \multirow{2}{*}{ Behavior } & \multirow{2}{*}{$\mathrm{N}$} & \multicolumn{3}{|c|}{ Time period } & \multirow[b]{2}{*}{ p-value } \\
\hline & & Morning & Afternoon & Night & \\
\hline Feeding & 1350 & $2.40^{\mathrm{a}}$ & $1.26^{\mathrm{b}}$ & $0.06^{\mathrm{c}}$ & $<0.0001 *$ \\
\hline Pool contact & 478 & $0.55^{\mathrm{b}}$ & $0.72^{\mathrm{a}}$ & $0.04^{\mathrm{c}}$ & $0.0439 *$ \\
\hline Moving & 4078 & $3.15^{\mathrm{b}}$ & $6.37^{\mathrm{a}}$ & $1.72^{\mathrm{c}}$ & $<0.0001 *$ \\
\hline Staying inside the handling area & 2763 & $5.16^{\mathrm{a}}$ & $1.36^{\mathrm{b}}$ & $1.09^{\mathrm{c}}$ & $0.0002 *$ \\
\hline Resting & 7342 & $8.31^{\mathrm{b}}$ & $8.78^{a}$ & $3.14^{\mathrm{c}}$ & $<0.0001 *$ \\
\hline Mud bathing & 274 & $0.17^{\mathrm{b}}$ & $0.59^{\mathrm{a}}$ & $0^{\mathrm{c}}$ & $0.0005^{*}$ \\
\hline Mutual rubbing & 478 & $0.53^{\mathrm{ns}}$ & $0.64^{\mathrm{ns}}$ & $0.15^{\mathrm{ns}}$ & 0.4329 \\
\hline Rubbing & 163 & $0.19^{\text {ns }}$ & $0.21^{\mathrm{ns}}$ & $0.04^{\mathrm{ns}}$ & 0.8436 \\
\hline Aggression & 71 & $0.07^{\mathrm{ns}}$ & $0.11^{\mathrm{ns}}$ & $0.01^{\mathrm{ns}}$ & 0.9281 \\
\hline Sexual behavior & 71 & $0.10^{\mathrm{ns}}$ & $0.09^{\mathrm{ns}}$ & $0.01^{\mathrm{ns}}$ & 0.8062 \\
\hline Copulation & 70 & $0.05^{\mathrm{ns}}$ & $0.13^{\mathrm{ns}}$ & $0.02^{\mathrm{ns}}$ & 0.3903 \\
\hline Foraging & 2749 & $3.36^{\mathrm{ns}}$ & $3.43^{\mathrm{ns}}$ & $0.79^{\mathrm{ns}}$ & 0.6489 \\
\hline Breastfeeding & 611 & $0.73^{\mathrm{ns}}$ & $0.69^{\text {ns }}$ & $0.26^{\mathrm{ns}}$ & 0.7626 \\
\hline Sleeping & 14483 & $7.71^{\mathrm{b}}$ & $7.19^{c}$ & $25.02^{\mathrm{a}}$ & $<0.0001 *$ \\
\hline Interaction & 135 & $0.16^{\mathrm{ns}}$ & $0.17^{\mathrm{ns}}$ & $0.04^{\mathrm{ns}}$ & 0.9538 \\
\hline Shackle & 334 & $0.08^{\mathrm{ns}}$ & $0.20^{\mathrm{ns}}$ & $0.64^{\mathrm{ns}}$ & 0.2319 \\
\hline Gnawing & 197 & $0.06^{\mathrm{ns}}$ & $0.44^{\mathrm{ns}}$ & $0.04^{\mathrm{ns}}$ & 0.2819 \\
\hline Others & 641 & $0.55^{\mathrm{ns}}$ & $0.96^{\mathrm{ns}}$ & $0.26^{\mathrm{ns}}$ & 0.8813 \\
\hline
\end{tabular}

$\mathrm{N}$, number of observations; Frequencies followed by the same letter in the same row do not differ from each other by the Chi-square test at the 5\% level $(\mathrm{P}<0.05) ;{ }^{\mathrm{ns}}=$ not significant at the 5\% level $(\mathrm{P}>0.05)$. 


\section{DISCUSSION}

The feeding behavior of peccaries was influenced by daily handling, with higher frequencies of feeding in the morning (2.40) and afternoon (1.26). Consequently, the animals moved constantly during these periods. The peccary has a pre-stomach consisting of four chambers (gastric pouch, cranioventral blind sac, caudodorsal blind sac, and direct compartment) and is therefore classified as omnivorous (Cavalcante Filho et al., 1998). This fact allows the animal to utilize fibrous feed through microbial fermentation of cellulose. Thus, lowcost products can be included in the diet of peccaries reared in captivity, as is the case of the present farm where $70 \%$ of the diet consists of seasonal foods (fruits, vegetables, and legumes), rendering it a profitable and sustainable alternative. Additionally, a higher frequency of staying inside the handling area was observed during the day, probably because of the location of the troughs, with the animals remaining inside the facility for feeding and/or drinking.

A semi-intensive production system of peccaries can increase the stress of animals because of the reduced space and lack of refuge areas, a fact that possibly impedes the expression of natural behavior. According to Sowls (2013), staying inside the handling area may be used as a protection mechanism in situations of conflicts that occur during feeding, i.e., this improvement may be used as a refuge by the animals. NogueiraFilho (1999) and Nogueira et al. (2010) suggested that peccary producers should provide a space of $185.5 \mathrm{~m}^{2}$ per animal in the facility to ensure social stability. In addition, the construction of several masonry feeders and drinking fountains inside the facility and/or throughout the paddock is necessary in order to avoid a dominance behavior of animals in during feeding and drinking, as well as to provide refuge areas (inside the handling area and reinforced concrete shackles), which can reduce the occurrence of agonistic acts. The installation of these structures in the production system should therefore improve the welfare of peccaries in captivity.

The frequencies of pool contact and mud bathing were higher in the afternoon (0.72 and 0.59, respectively). This finding can be explained by the greater solar incidence during this period, which is confirmed by the mean temperature $\left(25.8^{\circ} \mathrm{C}\right)$ and relative humidity $(59.5 \%)$ during the experimental phase (Estação..., 2019). Consequently, with increasing environmental temperature during the day, the animals tend to increase their water intake from the pool and bathing in mud puddles in order to regulate their body temperature (homeostasis) (Beale et al., 2018). In addition, mud bathing provides a physical barrier to ticks and other ectoparasites (Quintana and Rabinovich, 1993). Supporting the hypothesis, the farm supplies water through sprinklers during the dry periods of the year in order to form artificial mud puddles along the paddock for the welfare of the species. Therefore, mud puddles favor environmental enrichment, which reduces stress and stereotypical behaviors, improving the conditions of captivity (Baxter $e t$ al., 2011; Martins et al., 2015).

Moving and resting exhibited superior activity patterns during the day. The animals are probably more active during this period as a result of environmental factors (temperature and relative humidity) and maintenance requirements (Beale et al., 2018), in agreement with the patterns observed in this study.

White-lipped peccaries are diurnal animals (Mayer and Wetzel, 1987) and the sleeping behavior therefore predominated at night (25.02). However, behavioral activities such as moving and staying inside the handling area were also observed at night, but their frequencies were lower. Vinne et al. (2015) reported a predominance of behavioral activities during the day (morning and afternoon) in diurnal animals; however, the animals do not spend the whole day in continuous activity, as demonstrated in the present study by the frequencies of sleeping behavior in the morning (7.71) and afternoon (7.19).

The present results suggest that white-lipped peccaries (Tayassu pecari) are influenced by time of day (morning and afternoon). Feeders, drinkers and refuge areas must be provided in the facility, as well as mud puddles across the paddock. In addition, peccaries express behavioral patterns that are important for their welfare even in semi-intensive production systems. The findings of the present study increase our understanding of the maintenance of Tayassu pecari in semi-intensive systems, enabling appropriate facility/management 
planning that meets the requirements of the species in an ethical animal production system and contributing to conservation and zootechnical exploitation.

\section{CONCLUSIONS}

The present results contribute to the understanding of instinctive animal habits and to the development of nutritional, environmental and health management protocols that meet the requirement of peccaries in captivity. Future studies on captive white-lipped peccaries (Tayassu pecari) should focus on biological, conservationist and productive aspects.

\section{ACKNOWLEDGEMENTS}

We thank the Institutional Scientific Initiation Program (PIIC) of the Federal University of São João del-Rei.

\section{REFERENCES}

ALTMANN, J. Observational study of behavior: sampling methods. Behaviour, v.49, p.227-267, 1974.

BAXTER, E.M.; LAWRENCE, A.B.; EDWARDS, S.A. Alternative farrowing systems: design criteria for farrowing systems based on the biological needs of sows and piglets. Animal, v.5, p.580-600, 2011.

BEALE, P.K.; MARSH, K.J.; FOLEY, W.J.; MOORE, B.D. A hot lunch for herbivores: physiological effects of elevated temperatures on mammalian feeding ecology. Biol. Rev., v.93, p.674-692, 2018.

CAVALCANTE FILHO, M.F.; MIGLINO, M.A.; MACHADO, G.V.; BEVILACQUA, E.; NEVES, W.C. Comparative study of the arterial supply of the stomach of the white lipped peccary (Tayassu pecari) and of the collared peccary (Tayassu tajacu) [Linnaeus, 1789]. Braz. J. Vet. Res. Anim. Sci., v.35, p.20-24, 1998.

ELISSOR, J.E.; HARWELL, W.F. Mobility and home range of collared peccary in southern Texas. J. Wildl. Management, v.33, p.425-427, 1969.

ESTAÇÃO meteorológica de observação de superfície convencional. Brasília: INMET, 2019. Available in: <http://www.inmet.gov.br/portal/ index.php? $\mathrm{r}=$ estacoes/estacoesConvencionais>. Accessed in: 25 Oct. 2019.

FANG, T.G.; BODMER, R.E.; PUERTAS, P.E. et al. Certificación de pieles de pecaries en la Amazonía peruana: una estrategia para la conservación y manejo de fauna silvestre en la Amazonía peruana. Lima, Peru: [Wust], 2008. 202p.

HOFFMAN, L.C. Game as an alternative protein source: feed science. AFMA Matrix, v.25, p.54-55, 2016.

KILTIE, R.A. Bite force as a basis for niche differentiation between rainforest peccaries (Tayassu tajacu and Tayassu pecari). Biotropica, v.14, p.188195,1982

KILTIE, R.A.; TERBORGH, J. Observation on the behaviour of rainforest peccaries in Peru: why do white-lipped peccary form herds. Zool. Tierpychol, v.62, p.241-255, 1983.

KUMAR, S.A. Physiochemical properties and meat quality parameters of wild boarmeat: a review. Int. J. Eng. Management Res., v.8, p.137-144, 2018.

MARTIN, J.E.; ISON, S.H.; BAXTER, E.M. The influence of neonatal environment on piglet play behaviour and post-weaning social and cognitive development. Appl. Anim. Behav. Sci., v.163, p.69-79, 2015 .

MARTIN, P.; BATESON, P.F.R.S. Measuring behavior. An introductory guide. 3.ed. Cambridge, University Press, 2007. 190p.

MAYER, J.J.; WETZEL, R.M. Tayassu pecari. Mamm. Species, v.293, p.1-7, 1987.

NOGUEIRA, S.S.C.; SILVA, M.G.; DIAS, C.T.S. et al. Social behavior of collared peccaries (Pecari tajacu) under three space allowances. Anim. Welf., v.19, p.243$248,2010$.

NOGUEIRA-FILHO, S.L.G. Manual de criação de cateto e queixada. Viçosa: Embrapa, 1999. 70p.

QUINTANA, R.D.; RABINOVICH, J. Assessment of capybara (Hydrochaeris hydrochaeris) populations in the wetlands of Corrientes, Argentina. Wetland Ecol. Management, v.2, p.223-230, 1993.

SCHWEINSBURG, R.E. Home range, movements, and herd integrity of the collared peccary. J. Wildl. Management, v.35, p.455-460, 1971.

SOWLS, L.K. Javelinas and other peccaries: their biology, management, and use. 2.ed. Texas: A\&M University Press, 2013. 350p.

SOWLS, L.K. The peccaries. Arizona: Tucson, 1984. $251 \mathrm{p}$.

VINNE, V.V.D.; GORTER, J.A.; RIEDE, S.J.; HUT, R.A. Diurnality as an energy-saving strategy: energetic consequences of temporal niche switching in small mammals. J. Exp. Biol., v.218, p.2585-2593, 2015. 